\title{
COMPARATIVE STUDY OF E-GOVERNMENT ENTERPRISE ARCHITECTURE BY PRIMARY ATTRIBUTES OF 3 ASIAN COUNTRIES
}

\author{
Khakim Ghozali and Yudho Giri Sucahyo \\ Faculty of Computer Science, Universitas Indonesia, Kampus Baru UI Depok, Indonesia, 16424 \\ Email: khakim.ghozali@ui.ac.id
}

\begin{abstract}
Based on Waseda University International e-Government Ranking, announced in 2012, Singapore and Korea ranks first and third in the implementation of e-government. Whereas Indonesia ranks 33[6]. This study aims to conduct a comparative analysis of the implementation of e-government Enterprise Architecture in Korea, Singapore and Indonesia. Stages of the research conducted are reviewing literature on TOGAF framework, define the attribute comparison, analysis of EA implementation in each country and do a comparison of the EA of both countries. Attributes used for comparison EA are business architecture, information systems architecture and technology architecture. Korea and Singapore divide business area into two business areas, namely public services and support services. Indonesia has three business area. Korea split by sector information system development while Singapore users group split based information system. Indonesia has 4 main applications. Korea emphasizing mobile technology and the common component. While Singapore visible effort to increase the use of middleware. Indonesian technology solutions that enable information used accessed through various devices.
\end{abstract}

Keywords: comparative study, e-government enterprise architecture, TOGAF

\begin{abstract}
Abstrak
Waseda International University mengumumkan ranking e-Government pada tahun 2012, Singapura dan Korea menempati urutan pertama dan ketiga dalam pelaksanaan egovernment, sedangkan Indonesia menempati urutan 33. Penelitian ini bertujuan untuk melakukan analisis komparatif penerapan Enterprise Architecture e-government di Korea, Singapura dan Indonesia. Tahapan penelitian yang dilakukan adalah pengkajian literatur tentang framework TOGAF, penentuan perbandingan atribut, analisis implementasi EA di setiap negara dan perbandingan dari EA kedua negara. Atribut yang digunakan untuk perbandingan adalah EA arsitektur bisnis, arsitektur sistem informasi dan arsitektur teknologi. Korea dan Singapura membagi area bisnis menjadi dua, yaitu pelayanan publik dan layanan dukungan. Indonesia memiliki tiga area bisnis. Korea dibagi berdasarkan sektor pengembangan sistem informasi sedangkan Singapura berdasarkan kelompok pengguna sistem informasi. Indonesia memiliki 4 aplikasi utama. Korea menekankan teknologi mobile dan komponen umum. Sementara Singapura berupaya untuk meningkatkan penggunaan middleware. Solusi teknologi Indonesia yang memungkinkan informasi yang digunakan diakses melalui berbagai perangkat .
\end{abstract}

Kata kunci: studi perbandingan, arsitektur enterprise e-government, TOGAF

\section{Introduction}

According to Jaap Schekkerman (2008), EA is a complete expression of the enterprise; a master plan that acts as a power to do collaboration between aspects of business planning such as goals, visions, strategies and governance principles; aspects of business operations such as business constraints, the organizational structure, processes and data; aspects of automation such as information systems and databases, and technological infrastructure of the business such as computers, operating systems and networks.[2]

Why EA? EA is part of an ongoing development, not a project. EA is a unity of principles, methods and models used in the design and realization of organizational structure, business processes, information systems and infrastructure of 
an enterprise. EA describes the essence of the business, and the evolution of information technology. There are several roles of the EA. The first role is to provide an overview of how information technology can support the enterprise in achieving the vision and mission of the business strategy. The second role is to provide the opportunity for the enterprise to run a better business. The third role is to support business strategies that are constantly evolving, the fourth role is to direct and motivate the development of information technology activities [1].

Based on the UN e-Government Development Index Ranking in 2010, Korea won the first ranking of e-Government implementation of several countries that was ranked [8]. Based on Waseda University International e-Government Ranking, announced in 2012, Singapore ranks first in the implementation of e-government and followed by USA and Korea. Whereas Indonesia ranks 33 [6].

This paper will describe the comparison of egovernment EA that have been implemented in Singapore, Korea and Indonesia. Additionally, it will be known excess of EA implementation in Korea and Singapore so that the two countries could lead to motivation for other countries to develop the EA in accordance with the conditions of each country.

\section{Literature Review}

\subsection{TOGAF Architecture Development Method}

TOGAF was developed by the Open Group in 1995. TOGAF Architecture Development Method (ADM) gives an overview of how to create an EA of a particular organization in accordance with business needs. The scope of TOGAF implementation are products and services that are in the domain of business and industry, technical infrastructure based on open system building blocks, the definition of EA that include business process architecture, application architecture, data architecture, and technology architecture.[1]

Figure 1 shows that the phases of the EA development method using the TOGAF framework is as follows: Preliminary: Framework and Principles, Architecture Vision, Business Architecture, Information Systems Architecture (formed from the Data Architecture and Application Architecture), Technology Architecture, Opportunities \& Solutions, Migration Planning, Implementation Architecture Governance and Change Management. [1]

Based on Figure 1, TOGAF architecture has three main sections of EA which are:

1. Business / Business Process Architecture
This architecture defines the business strategy, governance, organization and key business processes.[1]

2. Information System Architecture

This architecture has two architectures namely data architecture and application architecture. Data Architecture outlines the structure of logical and physical data assets of an organization and data management resources. Applications Architecture provides a blueprint for the individual application systems to be implemented, the interaction between applications, and link the application with the organization's business processes.[1]

3. Technology Architecture

This architecture describes the capabilities of the hardware and software required to support the implementation of the business, data and application services including IT infrastructure, middleware, networks, communications, processing, and other standards.[1]

\section{Methods}

To carry out this research, we conducted several research stages as follows:

1. Review of the literature

Conducting literature review may take a few resources. The information collected from several sources such as the books that discuss EA, research articles which can be downloaded from the internet, the official website of the government of each country and other sites that contain information about the implementation of EA, and EA implementation brochures.

2. Determine the primary attribute to compare EA.

At this stage, the study will be related to one of the EA framework that is currently widely used, TOGAF. With a review of the stages of development of the EA will be able to know the primary attributes of an EA. The primary attribute will be used to compare the EA of the three countries.

3. Analysis of EA implementation in each country

At this stage, the EA implementation will be analyzed in each country based on the primary attributes.

4. Comparative analysis of the EA implementation of three countries

At this stage, the EA implementation of three countries will be compared based on the primary attribute. 


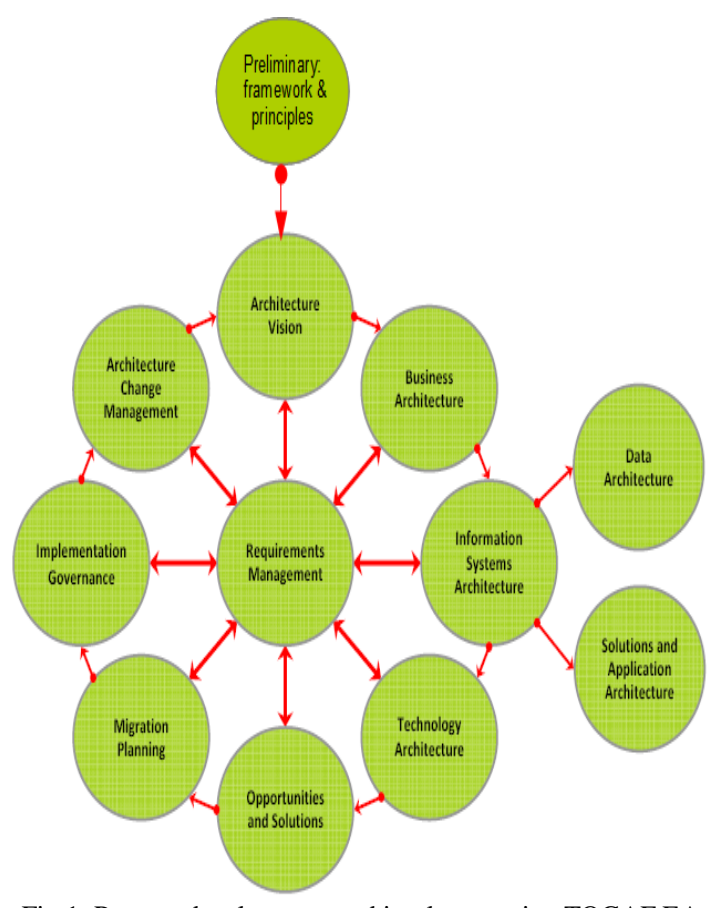

Fig 1. Process development and implementation TOGAF EA [1]

\section{Discussion}

\subsection{Identification of Key Attributes Comparison}

Based on the process of development and implementation of EA using the TOGAF framework as shown in Figure 1, there are nine stages of development of the EA implementation. Based on nine stages of the development of the primary attributes that will be used to compare the implementation of EA in both countries are: business architecture, information systems architecture and technology architecture.

\subsection{EA implementation in Korea}

\subsubsection{Business Architecture}

Korean government handles 2 types of services which are public services and supporting services. Public Service has 10 service area consists of 36 categories as shown in Table 1. The service areas consist of residents, environment, infrastructure, knowledge activities, social welfare, public health, culture and public life safety. Detail category of each service area can be seen in Table I [4].

The supporting services have 8 service areas that consists of 38 categories. Service type in the supporting area are audit, customer relations, legal, business management, human resources, finance, informatization, and general administration. Detail of the supporting service category can be seen in Table II [4].
TABLE I

PUBLIC SERVICE [4]

\begin{tabular}{ll}
\hline \multicolumn{1}{c}{ Area } & \multicolumn{1}{c}{ Category } \\
\hline residents & $\begin{array}{l}\text { Resident information, resident rights, family } \\
\text { support }\end{array}$ \\
environment & $\begin{array}{l}\text { Residential environment, natural } \\
\text { environment, weather/ climate }\end{array}$ \\
infrastructure & $\begin{array}{l}\text { Water/sewage, energy, traffic, distribution, } \\
\text { communication, resources }\end{array}$ \\
knowledge & Education, R\&D, knowledge/ information \\
activities & \\
social welfare & Social security, general welfare \\
public health & $\begin{array}{l}\text { Food and drug safety, disease control, } \\
\text { public health/ hygiene }\end{array}$ \\
overseas/ & North \\
Korea & $\begin{array}{l}\text { Immigration, South-North Cooperation, } \\
\text { Overseas Cooperation }\end{array}$ \\
economic & Business Open/ Closure, Tax/ Charges, \\
activities & $\begin{array}{l}\text { Jobs/ Labor, Assets, Consumer Protection, } \\
\text { Industry Support, Trade/ Commerce }\end{array}$ \\
culture life & Culture/Art, Leisure Activities \\
public safety & Emergency, Public Order, Trial, security \\
\hline &
\end{tabular}

\subsubsection{Information System Architecture}

Based on the National Information Society Agency obtained information that the total e-Gov projects are developed based on e-Gov framework as much as 293 project. Table 3 contains several egovernment projects that have been developed in 2009-2012. There are 18 sectors of e-government development carried out within a period of 3 years. Detail of the sectors are Administration, Transportation, Education, Medical, Military, Customs, Agriculture, Land, Local Government, Resident, Statistics, Social Security, Media, Patent, Tax, Port, Culture, and Athletics [3].

\subsubsection{Technology Architecture}

Based on the eGovFrame Korea, it is used to focus on the use of Open Source. Features of open source is used in several activities such as function design, policy setting, logical test, and physical test. Phase of function design and architecture defines the basic functions, the policy defines the policy settings for the selection of open source software. Logical test to test the candidate's open source software. Physical test for selecting and reflection 45 open source software. The major open sources used are Biz. Transaction (Spring \&22), Data (iBatis, Hibernate \& 1), Development tools (Eclipse \&3), Test Tool (Junit \& 5), Distribution Tool (Maven \&1), Configuration Management Tool (Subversion \&1), and Mobile UX (JqueryMobile $\& 4)$.

EGovFrame composition consists of the development environment, runtime environment, operation environment and management environment.[3] 
TABLE II

SUPPORTING SERVICES [4]

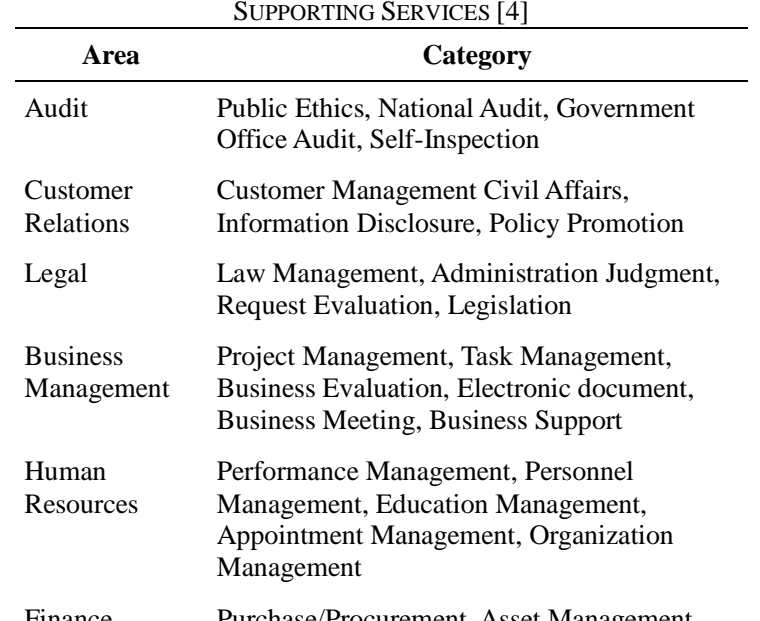

Finance Purchase/Procurement, Asset Management, Finance Management, Local Finance/Tax, National Property Management

Informatization IRM Administrative Information Security, Communication

General Library Management, Knowledge

Administration Management, Statistics Management, Record Management, Access Management, Facility Management

\begin{tabular}{|c|c|}
\hline \multicolumn{2}{|r|}{$\begin{array}{c}\text { TABLE III } \\
\text { MAJOR TOOLS AND SERVICES [3] }\end{array}$} \\
\hline Major Tool & Services \\
\hline $\begin{array}{l}\text { Implementation } \\
\text { Tool }\end{array}$ & $\begin{array}{l}\text { Provide editor, debugger, template, code } \\
\text { generation, etc functions. } \\
\text { - Basic tool for development such as } \\
\text { modelling (UML,DB, etc), source code editor, } \\
\text { inspection, etc. } \\
\text { - Code generation, based on template } \\
\text { (homepage, portal, biz function, mobile web). } \\
\text { - Common component ( } 229 \text { item) wizard for } \\
\text { easy to apply }\end{array}$ \\
\hline Test tool & $\begin{array}{l}\text { Provide testing, test reporting and coverage } \\
\text { analysis functions } \\
\text { - Support Junit based unit test } \\
\text { - Reort test result in HTML/ XML/ Excel } \\
\text { format } \\
\text { - Check test coverage and code area }\end{array}$ \\
\hline $\begin{array}{l}\text { Configuration } \\
\text { Management } \\
\text { Tool }\end{array}$ & $\begin{array}{l}\text { Provide source code and project output } \\
\text { configuration/ change management functions } \\
\text { - Subversion based source code and } \\
\text { documentation version configuration } \\
\text { - Suport major resource change management } \\
\text { and notification function. }\end{array}$ \\
\hline $\begin{array}{l}\text { Deployment } \\
\text { tool }\end{array}$ & $\begin{array}{l}\text { Provide source code and build automation } \\
\text { functions } \\
\text { - Maven based build } \\
\text { - Nexus repository based library management } \\
\text { - Hudson based build automation and build } \\
\text { result feedback }\end{array}$ \\
\hline
\end{tabular}

\subsubsection{Development environment}

Development environment consists of four major tools which are implementation tools, testing tools, configuration management tools, and deployment tools. It consists of 11 services such as editing, debugging, and others. All of services are used to develop an efficient e-Government implementation. Table III contains details of services provided by each of the major tool [3].

\subsubsection{Runtime Environment}

Runtime environment is a common module consisted of 6 service layers which are presentation, biz logic, persistence, integration, and foundation to run functions. There are 38 services such as IoC, Spring MVC, etc. type of services can be seen in table IV [3].

TABLE IV

RUNTIME ENVIRONMENT

\begin{tabular}{|c|c|c|}
\hline $\begin{array}{l}\text { Service } \\
\text { Group }\end{array}$ & ces & tions \\
\hline $\begin{array}{l}\text { Presentation } \\
\text { Layer }\end{array}$ & $\begin{array}{l}\text { MVC, } \\
\text { Security, } \\
\text { etc } \quad 5 \\
\text { services }\end{array}$ & $\begin{array}{l}\text { Provide an interface for UI } \\
\text { component and an architecture for } \\
\text { view implementation }\end{array}$ \\
\hline $\begin{array}{l}\text { Biz Logic/ } \\
\text { UX Layer }\end{array}$ & $\begin{array}{l}\text { Exception } \\
\text { handling, } \\
\text { CSS3 etc } 6 \\
\text { services }\end{array}$ & $\begin{array}{l}\text { Provide function to process } \\
\text { business/ UX logic, including } \\
\text { workflow control and UX } \\
\text { controller component. } \\
\text { UX: User eXperience }\end{array}$ \\
\hline $\begin{array}{l}\text { Persistence } \\
\text { Layer }\end{array}$ & $\begin{array}{l}\text { Data } \\
\text { Access, etc } \\
4 \text { services }\end{array}$ & $\begin{array}{l}\text { Provide functions for database } \\
\text { connection and CRUD function for } \\
\text { SQL operations }\end{array}$ \\
\hline $\begin{array}{l}\text { Integration } \\
\text { Layer }\end{array}$ & $\begin{array}{l}\text { Web } \\
\text { service, etc } \\
3 \text { services }\end{array}$ & $\begin{array}{l}\text { Provide functions such as Web } \\
\text { Service and meta data management } \\
\text { in order to interface with another } \\
\text { system }\end{array}$ \\
\hline $\begin{array}{l}\text { Foundation } \\
\text { Layer }\end{array}$ & $\begin{array}{l}\text { AOP, IoC } \\
\text { Container, } \\
\text { etc } 20 \\
\text { service }\end{array}$ & $\begin{array}{l}\text { Provide common modules as a core } \\
\text { function as well as additional } \\
\text { utilities for supporting the } \\
\text { application running }\end{array}$ \\
\hline
\end{tabular}

\subsubsection{Operation Environment}

Operation environment provides communication tools for efficient information system operation and monitoring tools for eGovFrame based applications [3].

\subsubsection{Common Component}

Common component are a set of reusable common modules when develop systems. Currently, 229 common component including mobile are provided [3].

\subsubsection{Utilization of eGovFrame}

eGovFrame provides information system lifecycle management functions across: analysis, design, implementation, test, and deploy [3].

\subsubsection{Mobile eGovFrame}

Template-based mobile services can be implemented by leveraging eGovFrame UX functions (runtime environment) and mobile common components [3]. 
TABLE V

COMMON COMPONENTS [3]

\begin{tabular}{|c|c|}
\hline Categories & Components \\
\hline \multicolumn{2}{|r|}{139 Technical components } \\
\hline $\begin{array}{l}\text { User } \\
\text { authentication }\end{array}$ & $\begin{array}{l}3 \text { components, including integrated user } \\
\text { authentication }\end{array}$ \\
\hline Security & $\begin{array}{l}8 \quad \text { components, including role/ } \\
\text { authorization, encyption }\end{array}$ \\
\hline Statistic & $\begin{array}{l}5 \text { components, including access statistics, } \\
\text { etc }\end{array}$ \\
\hline Collaboration & $\begin{array}{l}33 \text { components, including notice board, } \\
\text { mobile real time }\end{array}$ \\
\hline User support & $\begin{array}{l}51 \quad \text { components, including user } \\
\text { management, FAQ/Q\&A }\end{array}$ \\
\hline $\begin{array}{l}\text { System } \\
\text { management }\end{array}$ & $\begin{array}{l}25 \text { components, including menu, log, } \\
\text { system management }\end{array}$ \\
\hline Integration & $\begin{array}{l}6 \text { components, including system access, } \\
\text { mobile open }\end{array}$ \\
\hline \multirow[t]{3}{*}{$\begin{array}{l}\text { Digital asset } \\
\text { management }\end{array}$} & $\begin{array}{l}8 \text { components, including knowledge } \\
\text { management }\end{array}$ \\
\hline & 90 utility component \\
\hline & $\begin{array}{l}90 \text { components, including calendar, web } \\
\text { editor, format }\end{array}$ \\
\hline
\end{tabular}

\subsection{EA implementation in Singapore}

\subsubsection{Business Architecture}

Singapore government has two business areas, namely services to public and corporate and supporting services. Services to the public consists of 24 Lines of Business and Corporate Services and Supporting consists of 9 Line of Business. A total of 33 Line of Business and 137 Business Functions. Detailed of public services can be seen in Table VI [5].

Public services related to external parties that citizens, business and public stakeholders. While corporate and supporting services related to the internal government employees. The detailed list of the corporate and supporting services can be seen in Table VII [5].

\subsubsection{Information System Architecture}

The three main program is program developed for citizens, businesses and government.

\subsubsection{Programs for citizens}

Programs developed for citizens include: Access to Archives Online, Charity Portal, Citizen Connect, data.gov.sg, Donor Care @ HSA, eVisitor, E-Withdrawal, eCitizen Portal, Enhanced Immigration Automated Clearance System (eIACS), iCanBook, mGov @ SG, Mobile Government, my cpf, OneInbox, Online Consultation Portal, Reaching Everyone for Active Citizenry@ Home (REACH), Singapore Online Search Engine, SingPass, Subordinate Court
System, The Electronic Medical Record Exchange (EMRX), The National Service Portal (NS Portal), The Singapore Government Online Portal (gov.sg), TRUST, and web Content Accessibility Guidelines [7].

TABLE VI

SERVICES TO THE PUBLIC

\begin{tabular}{l}
\hline$\quad$ Services \\
\hline 1.Family development, \\
2.Community development, \\
3.National defense, \\
4.Homeland security, \\
5.Emergency \& crisis management, \\
6.Crime prevention \& protection, \\
7.Legal\&Judicial activities \\
8.Economical Development \\
9.Monetary control \& public fund management \\
10.International\&trade relations \\
11.Education \\
12.Health \\
13.Energy Management \\
14.Environmental management \\
15.Urban planning, Infra \& public fasilities, housing \\
16.Culture\&Recreation \\
17.Transportation \\
18.Regulatory Compliance \& Enforcement \\
19.Financial assistance \\
20.Monetary Collection \\
21. Workforce Management \\
22.Information management\&consulting \\
23.Research\& Development \\
24.Asset management \\
\hline
\end{tabular}

TABEL VII

CORPORATE AND SUPPORTING SERVICES

$$
\text { Service }
$$

1.Project \& Logistic Management

2.Administrative Services

3.Corporate\&Planning Development

4.Information Technology Management

5.Public Communication

6.Policy Development, Planning\& Management

7.Profesional Services

8.Finance

9.Human Resource

\subsubsection{Programs for businesses.}

Programs developed for business include Bizfile, Business incentive Profiler, CoreNet, GeBIZ, OBLS, OneMap, SG-SPACE, STARS, and Unique Entity Number (UEN) [7].

\subsubsection{Program for government.}

Programs developed for government include Cloud Computing for Government, Cube, Government Web Service Exchange, Infocomm Security Masterplan, Knowledge Management, Networked Management, Public Service Infrastructure, Singapore Government Enterprise Architecture (SGEA), Standard Operating Environment (SOE), Web Service, Whole-ofGovernment Enterprise Architecture (EA WOG), and Workplace of the Future [7]. 


\subsubsection{Technology Architecture}

Technology architecture consists of several components, namely security, application, collaboration and workflow, middleware, data management, internet and intranet, platforms, networks, and distributed management environment. Technical Reference Model can be seen in Figure 2 [5].

\subsection{EA implementation in Indonesia}

\subsubsection{Business Architecture}

There are three purposes of the e-government in Indonesia, namely: administration, public services and partnerships. Administration aims to improve the efficiency of state expenditures for administrative activities. Public service aims to connect between the government and the public. Partnership aims to establish interaction with all stakeholders government, business and citizens. Table VIII describes the functions and domains in e-government [9].

TABLE VIII

FUNCTIONS AND DOMAINS IN E-GOVERNMENT

\begin{tabular}{ll}
\hline \multicolumn{2}{c}{ Function } \\
\hline $\begin{array}{l}\text { Administration } \\
\text { administration) }\end{array}$ & (e- Population \\
Public Services & (e- Licensing, Taxation, Government \\
Citizen and & e- Procurement, State Finance, State \\
service) & Policies and Regulations \\
Partnership & All of government domain \\
\hline
\end{tabular}

\subsubsection{Information System Architecture}

Four main applications in the information system architecture of Indonesian e-Government framework are e-administration, e-Citizen, eServices and e-Society [9].

\subsubsection{Technology Architecture}

Technology solutions enable information used accessed through various devices such as computers, laptops, mobile phones (mGovernment), or other electronic devices (uGovernment). Illustration u-Government can be seen in Figure 2. Presentation related to the appearance of the application that can be accessed by the user. Various applications are stored in a server application. The data that can be accessed by the application are stored in the database server so that it can be accessed through the network in the form of an ethernet network (LAN), Network ring (WAN), and the internet [9].

\subsection{EA Implementation comparisons between the three countries}

This section will discuss EA comparison of Korea, Singapore and Indonesia. The description is based on a comparison of each primary attribute comparison.

Table IX shows the comparison of business architecture of the three countries. Korea and Singapore have two business areas, namely public services and supporting services. Korea has 10 areas of public services (36 categories) and 8 service areas (38 categories). Korea has a total of 76 categories of service. Singapore has 24 public services and 9 corporate and support services. There are 137 business functions in Singapore whereas Indonesia has 3 business area, namely administration, public services and partnerships.

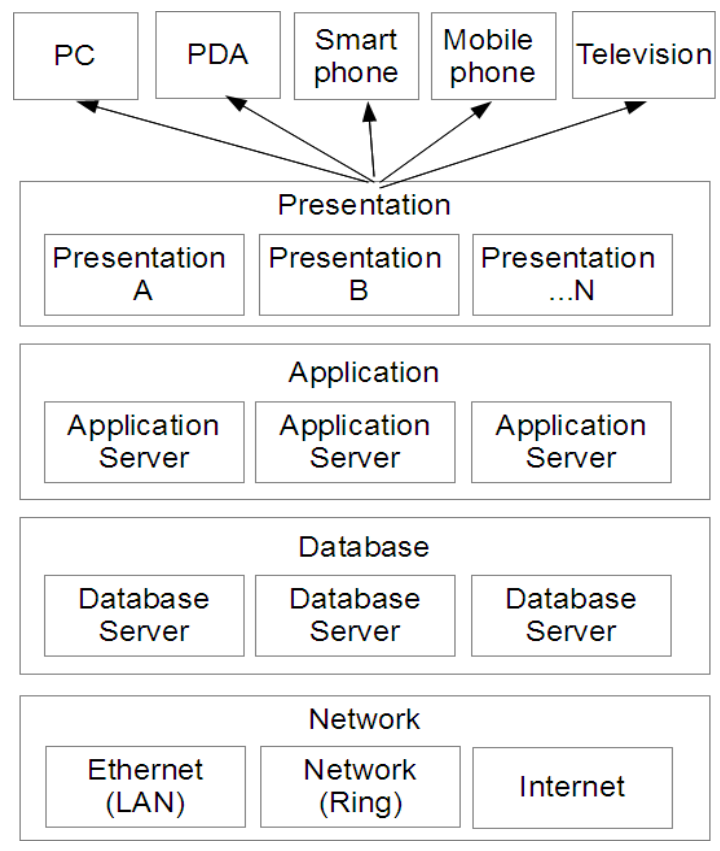

Fig 2. Indonesia technology architecture[9]

TABLE IX

COMPARISON OF BUSINESS ARCHITECTURE

KRA 2 business areas (public services and support services). Public service area comprises 10 services (36 categories). Support services consist of 8 service area (38 categories)

SNG 2 business areas (public service, corporate service and support). Public Service consists of 24 service and support and corporate services consist of 9 services

INA 3 business area (administration, public services and partnerships).

KRA:Korea, SNG: Singapore, INA: Indonesia

Table X shows the comparison of information system architecture of the three countries. Korea split information system development by sector while Singapore split information system by user groups. Indonesia has 4 main applications in the information system architecture namely eadministration, e-Citizen, e-Services and e-Society. 
TABLE X COMPARISON OF INFORMATION SYSTEM ARCHITECTURE

KRA Total project done amounted to 293 information system. While the 2009-2012 year, there are 18 information systems developed

SNG Programs for the citizens consists of 11 information systems. The business program consists of 9 information systems. Program for government consists of 12 information systems.

INA 4 main information system

Table XI below shows the comparison of Technology Architecture of the three countries. In the table shows that Korea emphasize in the mobile technology and the common component. By using the common component we can improve the use of components simultaneously so that the software development process can be faster and avoid redundancy. On the other hand, Singapore has visible effort to increase the use of middleware. Singapore gives attention to the management of information technology that distributed across multiple locations. Indonesian government provides technology solutions that enable information used accessed through various devices such as computers, laptops, mobile phones (m-Government), or other electronic devices ( $\mathrm{u}-$ Government).

TABLE XI COMPARISON OF TECHNOLOGY ARCHITECTURE

KRA development environment, runtime environment, operation environment, management environment, common component, utilization of eGovFrame, mobile eGovFrame

SNG Security, application, collaboration \& workflow, middleware, data management, internet \& intranet, platform, network, distributed environment management

INA Tool, presentation, aaplication, database and network.

\section{Conclusion}

In this study, the attributes used for EA comparison are business architecture, information systems architecture, and technology architecture. Business architecture in Korea and Singapore are divided into two business areas, namely public services and support services. Korea has 10 areas of public services (36 categories) and 8 service area (38 categories). Singapore has 24 public and 9 services and corporate and supporting services. Indonesia has 3 business areas.

Korea split information system development by sector while Singapore split information system based on users group. Indonesia has 4 main applications.

Korea emphasizing the mobile technology and the common component while Singapore visible effort to increase the use of middleware. Singapore gives attention to the management of information technology that distributed across multiple locations. Indonesia government provides technology solutions that enable information used accessed through various devices.

\section{References}

[1] Alan McSweeney, Enterprise Architecture and TOGAF (The Open Group Architecture Framework), 2000.

[2] Jaap Schekkerman, Enterprise Architecture Good Practices Guide, Trafford Publishing, 2008.

[3] Ministry of Public Administration and Security, e-Government Standard Framework, Open Source Open Platform.

[4] NIA, Korea e-Gov't: Government EA (Enterprise Architecture) \& e-Gov't Standard Framework, 2011

[5] Pallab Saha, Government Enterprise Architecture in Singapore: Issues, Practices and Trends, Government Enterprise Architecture as Enabler of Public Sector Reform, The World Bank, Washington DC, April 17th, 2008

[6] Toshio Obi, The 2012 Waseda University International e-Government Ranking released, 2012

[7] http://www.egov.gov.sg, Master Plan eGov, Singapore eGov

[8] www.unpan.org/e-government, United Nations E-Government Survey 2012 - E-Government for The People, United Nations, New York, 2012.

[9] Albaar Rubhasy, Zainal A. Hasibuan, Muhaemin, Kerangka Arsitektur E-Government Nasional Menggunakan Pendekatan TOGAF: Mewujudkan Layanan Prima Berbasis TIK, 2010 